\title{
A Critical Appraisal of the Legal and Policy Frameworks for the Protection of Women's Rights in Nigeria
}

\author{
Dr. Enobong Mbang Akpambang \\ LL.B (Hons.), LL.M., Ph.D., B.L \\ Senior Lecturer and Acting Head, \\ Department of Public Law, \\ Ekiti State University, Ado-Ekiti, Nigeria \\ $\mathrm{He}$ is a Barrister and Solicitor of the Supreme Court of Nigeria
}

\begin{abstract}
The article critically examined the legal and policy frameworks that have been put in place to protect women's rights in Nigeria. The major aim of the research was to x-ray the relevant laws and policies with a view to finding out their effectiveness and possible constraints or shortcomings. It was discovered in the research that while in recent times, there have been robust increase in the number of laws and policies that have been enacted to protect the rights of women in Nigeria, there have been some lapses in some of the laws and governmental policies which correspondingly affected their enforcements and efficacy. The article concluded that while it is commendable that some relevant legal framework and policies have been enacted by the government at various levels to address issues of women's rights, the government and relevant stakeholders are still required to do more to promote and protect the rights of women in Nigeria. The article also recommended, inter alia, that the Nigerian government and relevant stakeholders should exercise strong commitments towards the promotion of women's rights in the country. One of such ways is by amending some of the laws and revising some policies where loopholes have been identified in the article with a view to achieving the noble aims and objectives for enacting them as well as bringing them into conformity with global and regional instruments.
\end{abstract}

Keywords: Women's Rights, Female Genital Mutilation, Gender-Based Violence, Domestic Violence, Widowhood Practices, Rape, Sexual Offences

\section{Introduction}

In Nigeria, like many other African countries, women suffer a lot of discriminations and deprivations as a result of their gender. This is partly due to the prevailing cultural system of patriarchy ${ }^{1}$ coupled with religious influences which consider women as lower in status to men. The mentality of considering women as being subservient to men and consequently play insignificant roles either at home or in societal governance was recently voiced out by the incumbent Nigerian president at an international forum when in response to criticisms from his wife ${ }^{2}$ he stated, "I don't know which party my wife belongs to, but she belongs to my kitchen and my living room and the other room." ${ }^{3}$ This no doubt, drew serious castigation from members of the public. ${ }^{4}$

\footnotetext{
${ }^{1}$ See generally, Cheluchi Onyemelukwe, "Legislating on Violence against Women: A Critical Analysis of Nigeria's Recent Violence against Persons (Prohibition) Act, 2015," (2016) 5(2) Depaul Journal of Women, Gender and the Law, p.2. Retrieved from<http://via.liabrary.depaul.edu/jwgl/vol5/iss2/3>.

Accessed on 12 November 2017.

${ }^{2}$ Mrs. Aisha Buhari had in an earlier interview hinted that the husband's government had been hijacked by a cabal and that she might not support his candidacy in a subsequent election unless the president changed and took full control of his government.

3 See BBC News-Africa, "Nigeria's President Buhari: My wife belongs in Kitchen," (14 October 2016) BBC NEWS. Retrieved from https:/www.bbc.com/news/world-africa-37659863. Accessed on 30 December 2019. Unfortunately, President Muhammadu Buhari was sitting next to the German Chancellor, Angela Merkel, when he made the statement.

${ }^{4}$ See Benjamin Kentish, "Nigeria's President Mohammadu Buhari criticised after saying wife 'belongs in the kitchen."' (15 October 2019) Independent. Available at https://www.independent.co.uk/news/world/africa/nigeria-president-muhammadubuhari-wife-belongs-in-kitchen-a7362806.html. Accessed on 30 December 2019. See also, Cletus Ukpong, "How Buhari sparked internet debate with "my wife belongs to my kitchen" comment," Premium Times (17 October 2016). Available at
} 
The consideration and treatment of women in such light has stirred up the agitation for the recognition women's rights as an integral and inseparable constituent of human rights. Agitation for and the need for the protection of women's right is not a recent development. As a matter of fact, traces of such campaigns could be found in the Christian Bible. A typical biblical example of a protest for the acknowledgment of the female gender's right to family inheritance was unprecedentedly launched by the five daughters of Zelophehad who approached Moses and all the congregation of Israel to demand for the inheritance of their father who had died intestate without a male child. Through divine guidance, the law of inheritance in Israel was re-written. The new position under the Mosaic Law stated that "[i]f a man die, and have no son, then ye shall cause his inheritance to pass unto his daughter." ${ }^{, 5}$ However, the right to family inheritance by such a female member limited her choice of marriage to only members of her family. ${ }^{6}$

In the modern world, it may be recalled that in 1948, the United Nations proclaimed the Universal Declaration of Human Rights (UDHR) ${ }^{7}$ which inter alia, recognised that all human beings are equal before the law and are accordingly entitled without any discrimination to equal protection of the law $;{ }^{8}$ freedom from torture, cruelty, inhuman or degrading treatment ${ }^{9}$ as well as right to life, liberty, security of person, ${ }^{10}$ and equality in dignity and rights. ${ }^{11}$ The UDHR has remained a source of inspiration for advocating for the protection and recognition of human rights at the global, regional and national levels.

With specific reference to women's rights, the United Nations Organisation adopted the Convention on Political Rights of Women in $1954,{ }^{12}$ which inter alia, encouraged women to participate in the government of their country, including the right to vote and be voted for. ${ }^{13}$ Subsequently, there were other global regional agreements which sought to protect the rights of women. These include, but not limited to the International Covenant on Economic, Social and Cultural Rights, ${ }^{14}$ International Covenant on Civil and Political Rights, ${ }^{15}$ the African Charter on Human and Peoples' Rights, ${ }^{16}$ Convention on the Elimination of All Forms of Discrimination against Women [CEDAW], ${ }^{17}$ Declaration on the Elimination of Violence against Women, ${ }^{18}$ Convention for the Suppression of the Traffic Persons and of the Exploitation of the Prostitution of others, ${ }^{19}$ Convention on Consent to Marriage Minimum Age for Marriage and Registration of Marriages, ${ }^{20}$ the Protocol to the African Charter on Human and Peoples Rights on the Rights of Women in Africa, ${ }^{21}$ and the Beijing Declaration and Platform for Action. ${ }^{22}$

https://www.premiumtimesng.com/news/top-news/212938-buhari-sparked-internet-debate-wife-belongs-kitchen-

comment.html. Accessed on 30 December 2019.

${ }^{5}$ The Holy Bible, Book of Numbers, Chapter 27: 1-11 (The New King James Version).

${ }^{6} \mathrm{Ibid}$, Book of Numbers, Chapter 36: 1-13.

${ }^{7}$ Adopted and proclaimed by UN General Assembly Resolution 217 A (III) of 10 December 1948 Text: UN Document A/810, p. 71 (1948).

${ }^{8}$ Ibid, Article VII.

${ }^{9}$ Ibid, Article V.

${ }^{10}$ Ibid, Article III.

${ }^{11} \mathrm{Ibid}$, Article I.

12193 UNTS 135, adopted on 31 March 1953, entered into force on 7 July 1954. The Convention was perhaps the first global treaty that protected and recognised the equal position of women to exercise political rights. A text copy of the Convention is available at <http://hrlibrary.umn.edu/instree/e2cprw.htm〉. Accessed on 17 December 2019.

${ }^{13}$ Ibid, Articles 1-3.

${ }^{14}$ Adopted and opened for signature, ratification and accession by UN General Assembly Resolution 2200A (XXI) of 16 December 1966. Entered into force on 3 January 1976, in accordance with Article 27. Text: United Nations, Treaty Series, vol. 993, p. 3. See for instance, Articles 2, 7, 10 and 11 thereof. Nigeria ratified the Covenant on 29 July 1993.

${ }_{16}^{15}$ See for instance, Articles 3, 23, 24, 25 and 26 thereof. Nigeria ratified the Covenant on 29 July 1993.

${ }^{16}$ See for example, Articles 2, 3, 18, 27 and 28 thereof.

${ }^{17}$ See for instance, Articles 1-11 thereof. Nigeria ratified this convention on 13 June 1985.

${ }^{18}$ See Articles 1-6 thereof.

${ }^{19}$ See Articles 2-28 thereof.

${ }^{20}$ See Articles 1-10 thereof.

${ }^{21}$ See generally Articles 1-32 thereof. Ratified by Nigeria on 16 December 2004.

22 This was a product of the fourth World Conference on Women held in September 1995 at Beijing, China, where world leaders reaffirmed their commitments to the "equal rights and inherent human dignity of women and men" and to "ensure the full implementation of human rights of women and of the girl child as an inalienable, integral and indivisible part of all human rights and fundamental freedoms." See generally paragraphs 8, 9, 14, 23 and 24 of the Beijing Declaration of 1995. 
In line with the requirements of these international and regional instruments, the Nigerian government, both at the national and State levels, ${ }^{23}$ have made laws and policies aimed at promoting the rights of women and the girl child. The article, therefore, seeks to critically examine the Nigerian legal and policy frameworks targeted at protecting women's right in Nigeria as well as investigates some of the possible challenges inhibiting the efficiency of these laws and policies.

\section{Nigerian Legal Frameworks For The Protection Of Women's Rights}

In this section of the work, we shall examine some domestic or national legislation enacted either at the national or state level to protect and promote the rights of women in Nigeria.

\subsection{The Constitution of the Federal Republic of Nigeria 1999 (as amended)}

The 1999 Constitution contains a number of provisions targeted at protecting the rights of women. First, the"social objectives" clause of section 17 recognises the right to equal pay for equal work without discrimination by reason of sex or any other reason whatsoever. ${ }^{24}$ The section also protects the sanctity of the human person, human dignity as well as equality of every citizen to rights, obligations and opportunities before the law. ${ }^{25}$ The enforceability of this provision is however doubtful in the face of section 6 (6)(c) of the 1999 Constitution. ${ }^{26}$ The consolation nonetheless is that the fundamental objectives and directive principles of state policy contained in chapter II of the 1999 Constitution can be rendered justiciable either where it is connected to the enforceable rights contained in the fundamental rights provisions of chapter IV of the 1999 Constitution or stated in the already domesticated African Charter on Human and Peoples' Rights. ${ }^{27}$

Second, the citizenship provisions under the 1999 Constitution in its section 25 takes into account the rights of women as it gives equal citizenship right by birth to both men and women without discrimination.However, this equality does not extend to citizenship by registration. Thus, while it is possible for a foreign woman married to a Nigerian man to become a Nigerian citizen by registration, there is no such constitutional arrangement for a foreign man married to a Nigerian woman ${ }^{28}$ The only option available to the alien husband is to naturalise if he desires to become a Nigerian citizen and the procedures are not the same. ${ }^{29}$

Third, section 29(1) of the 1999 Constitution 1999 gives equal opportunityto "any citizen of Nigeria of full age" to renounce his/her Nigerian citizenship. But a further perusal of the section shows that the 1999 Constitution has tacitly promoted early girl-child marriage. This is because of its dual interpretation of what constitutes "full age" to qualify for the citizenship renunciation. The first arm of the interpretation relates to a person who is of "the age of eighteen years and above." ${ }^{\prime 30}$ The second arm of the interpretation is that "any woman who is married shall be deemed to be of full age." ${ }^{, 31}$ The implication of this is that a girl child who is married out at the age of thirteen years old is constitutionally deemed to be an adult whereas her male counterpart will not be so recognised until he attained the age of eighteen years. This is highly discriminatory. There is need therefore, to amend this constitutional provision by deleting the phrase, "any woman who is married shall be deemed to be of full age."

Fourth, under the fundamental rights' chapter, the 1999 Constitution provides for a right to freedom from discrimination. ${ }^{32}$ However, this anti-discriminatory provision of the 1999 Constitution is apparently a mere mirage and a pyrrhic victory in view of the qualifications stated in sub-section (3) of that section. The sub-section acknowledges that [n]othing in subsection (1) of this section shall invalidate any law by reason only that the law imposes restrictions with respect to the appointment of any person to any office under the State or as a member of the armed forces of the

\footnotetext{
${ }^{23}$ Note that the term, "government" has been defined to include "the Government of the Federation, or of any State, or of a local government council or any person who exercises power or authority on its behalf." See Constitution of the Federal Republic of Nigeria (as amended), section 318.

${ }^{24}$ Ibid, section 17(3)(a) and (e).

${ }^{25} \mathrm{Ibid}$, section $17(2)$ (a) and (b).

${ }^{26}$ See also Okogie v. Lagos State (1981) 2 NCLR 337 at 350.

27 See African Charter on Human and Peoples' Rights (Ratification and Enforcement) Act, Cap. A9, Laws of the Federation of Nigeria, 2004. Compare Articles 15, 16 and 17 thereof with section 17 (3)(b)(d) and(e). See also Abacha v. Gani Fawehinmi (2000) FWLR (Pt. 4) 533; Re-Olafisoye (2004) All FWLR (Pt. 198) 1106; Attorney-General, Ondo State v. Attorney- General of the Federation (2002) FWLR (Pt. 111) 1972.

${ }^{28}$ See section 26 of the 1999 Constitution for a comprehensive procedure on citizenship by registration.

${ }^{29}$ See section 27 of the 1999 Constitution for a detailed procedure on acquisition of citizenship by naturalisation.

${ }^{30}$ See section 27 (4)(a) of the 1999 Constitution.

${ }^{31}$ See section 27 (4)(b) of the 1999 Constitution.

${ }^{32}$ See section 42 (1)(a) and (b) of the 1999 Constitution.
} 
Federation or a member of the Nigeria Police Force or to an office in the service of a body corporate established directly by any law in force in Nigeria.

This qualification has more or less rendered impotent the provisions of subsection (1) which seeks to abolish all forms of discriminatory practices against women. For instance, the Police $\mathrm{Act}^{33}$ contains some discriminatory provisions encouraged by section 42(3) of the Constitution. For example, section 124 of the Police Act makes provision regarding a woman police officer desirous of getting married to apply for permission to do so. In addition she is required to furnish the police authority with the name, address and occupation of the intended husband.The requisite permission would only be granted if the intended husband is a person of good character and the applicant has served the Police Force for a period of not less than three years.

As a matter of fact, while section 118(g) of the Act forbids the enlistment of a married woman into the Police Force, section 127 thereof goes further to provide that an unmarried woman police officer who becomes pregnant outside wedlock "shall be discharged from the Force, and shall not be re-enlisted' unless with the permission of the InspectorGeneral of Police."It is submitted that the above requirements under the Police Act are highly discriminatory against women as there are no corresponding provisions in relation to their male counterparts. ${ }^{34}$ In this respect, the Convention on the Elimination of All Forms of Discrimination against Women (CEDAW) boldly enjoins State parties to:

...take all appropriate measures to eliminate discrimination against women in the field of employment in order to ensure, on a basis of equality of men and women, the same rights, in particular: (a) [t]he right to work as an inalienable right of all human beings; (b) [t]he right to the same employment opportunities, including the application of the same criteria for selection in matters of employment. ${ }^{35}$

Furthermore, although as seen earlier, the constitutional provision regarding citizenship by birth is not discriminatory, yet it is mute regarding the actual state of origin of a married woman. Should a married woman claim her State of origin or the husband's place of origin, for instance, in relation to employment, elective positions or political appointments? Few examples could be used to illustrate the sensitivity of this problem. Sometime in 2012, the then Chief Justice of Nigeria, Hon. Justice Maryam Aloma Mukhtar declined to administer the oath of office on a newly appointed female Justiceof the Court of Appeal on the strength of a petition alleging that being an indigene of Anambra State and married to an Abia State man, the judicial officer could not be allowed to fill in the Abia State slot at the Court of Appeal. ${ }^{36}$ Similarly, the appointment of Dr. (Mrs.) Ngozi Okonjo-Iwealaas a Minister by the then President Obasanjo under the Abia State slot was a subject of resistance. It was contended by that though Mrs. Ngozilweala was married to an Abia State man, her State of origin was Delta State. As a matter of fact, neither State wanted her to fill its quota for the ministerial appointment. ${ }^{37}$

In addition, when Mrs. Josephine Anenih was appointed as a Minister of Women Affairs under her State of origin's slot, Anambra State, there was opposition from her State regarding her appointment on the ground that having been married to an indigene of Edo State, she ought to have been given the Edo State slot. ${ }^{38}$ These illustrated cases have made a writer to question whether "a married woman is a Stateless person?" 39 Unfortunately, the provisions of sections 14(3) and (4) of the 1999 Constitution which provide for federal character in relation to appointments have not addressed this sensitive issue. Thus, there is need for a constitutional or statutory definition of the actual State of origin of a married woman for purposes of employment, political appointments or elective position. ${ }^{40}$ Marital status of a woman should not render her stateless or deprive her of her due entitlements or indigeneity.

\footnotetext{
${ }^{33}$ Cap. P19, Laws of the Federation of Nigeria, 2004.

${ }^{34}$ It is however, heart warming that at the time of writing this article, there was a move by the National Assembly to amend the Police Act by expunging some gender-discriminatory provisions like sections 122, 123, 124 and 127 of the statute book. See NAN, "Senate Reviews Pre-Independence Law Requiring Policewomen to Get Permission to Marry," (Lagos, 12 December 2019) The Punch. Available at https://punchng.com/senate-reviews-pre-independence-law-requiringpolicewomen-to-get-permission-to-marry/. Accessed on 12 December 2019.

${ }^{35}$ See CEDAW, Article 11(1)(a)and (b).

${ }^{36}$ See generally, Pini Jason, "Married but Stateless," (Lagos, 13 November 2012) Vanguard. Available at <https://www.vanguardngr.com/2012/11/oshiomhole-the-road-is-still-long/>.Accessed on 16 April 2018.

${ }^{37}$ Ibid. See also generally Joy Ngozi Ezeilo, Women, Law \& Human Rights: Global and National Perspectives (Enugu/Abuja: Acena Publishers, 2011) 118.

38 Pini Jason, "Married but Stateless," ibid.

${ }^{39}$ Ibid.

40 Joy Ngozi Ezeilo, Women, Law \& Human Rights: Global and National Perspectives, op. cit., p. 119. 


\subsection{The Criminal Code Act $^{41}$}

The statute contains some penal statutory provisions directed at protecting the sexual and reproductive rights of the female gender. Such sexual offences prohibited under the Act for the protection of the female gender include, but not limited to provisions on rape ${ }^{42}$ indecent assault, ${ }^{43}$ defilement, ${ }^{44}$ abduction, ${ }^{45}$ seduction and prostitution. ${ }^{46}$ However, this Act has been criticised for various reasons. First, the discriminatory treatment of an unlawful indecent assault of a woman or girl as a misdemeanour with the prescribed punishment of two years imprisonment ${ }^{47}$ as against the imposition of seven years imprisonment for a similar offence regarding a male victim ${ }^{48}$ is seriously frowned at. Second, the narrow interpretation of the concept of rape(i.e. penile-vagina penetration) under the law does not stand to reason in the face of current realities across the globe. Third, the limitation on the right to abortion stipulated under the Act is considered as a violation of the sexual and reproductive health rights protected under such global and regional treaties like CEDAW and the Protocol to the African Charter on Human and Peoples' Rights on the Rights of Women in Africa 2003 which entitle women to available, accessible and acceptable abortion care. ${ }^{49}$ It is suggested that the scope of "legal abortion" as presently construed under the statute ${ }^{50}$ should be expanded to cover cases of rape and incestuous relationships

\subsection{The Penal Code Act ${ }^{51}$}

Like its counterpart, the Penal Code (PC) contains some provisions aimed at protecting the sexual reproductive rights of women and girls. ${ }^{52}$ However, the PC contains a provision which encourages a husband to beat his wife if it is for the purpose of correcting or chastising the wife. ${ }^{53}$

${ }^{41}$ Cap. C38, Laws of the Federation of Nigeria, 2004.

${ }^{42}$ Ibid, sections 357-359.

${ }^{43}$ Ibid, section 360 .

${ }^{44}$ See sections 218 and 219 thereof. Specifically, section 218 of the Criminal Code requires that to succeed in the prosecution of a suspect for the defilement of a girl less than thirteen years of age, conviction cannot be secured upon an uncorroborated testimony of at least one witness. Query: since sexual assault hardly occurs in the full glare of the public, what happens where the victim was attacked and overpowered by the assailant on a lonely footpath in a remote village where she could not attract witnesses who could corroborate her testimony? This point can better be illustrated with the facts in the case of $N a$ 'an Upahnar \& Anor v. The State (2003) FWLR (Pt. 139) 1512 at pp. 1525, 1529, 1530, where the appellants were alleged to have accosted the prosecutrix at the cross road while she was returning from fetching water from the stream and dragged her into the bush and sexually assaulted her. While the $1^{\text {st }}$ appellant penetrated the private part of the prosecutrix with his penis, the $2^{\text {nd }}$ appellant held her legs and put sand into her mouth to stifle her cries and protests. The evidence of the prosecutrix was corroborated by PW2 who was going to his farm when he heard the cries of the victim and came in that direction to see the $1^{\text {st }}$ appellant on top of the prosecutrix copulating with her while the $2^{\text {nd }}$ appellant held her legs. Unfortunately, though the appeal was dismissed, the Court of Appeal still maintained that solitary evidence of the prosecutrix cannot establish offence of rape and that the "nature and content of the corroborative evidence must not only corroborate and support the prosecutrix's claim that the accused had raped her by penetrating into her vagina, it must also unequivocably implicate the accused person." Consequently, the appellate court noted that while the testimony of the PW2 may corroborate the evidence that the $1^{\text {st }}$ appellant was on top of the prosecutrix and that the $2^{\text {nd }}$ appellant held her legs yet "the probative value of PW2's evidence is not as corroborating the actual act of penetration-" (see pages 1530, 1531 of the report). On the other hand, in Hema Ukershima v. The State (2003) FWLR (Pt. 137) 1117, the appellant's conviction for the offence of rape was set aside on appeal due to lack of corroborative evidence. The allegation against the appellant was that he got hold of the prosecutrix on a bush path in the night around $10 \mathrm{pm}$ and took her to a nearby house where he had sexual intercourse with her forcefully. He denied the allegation and pleaded alibi. See also Okoyomon v. The State (1973) NMLR 292, where the Nigerian Supreme Court also set aside the appellant's convict due to lack of corroborating evidence of penetration of the prosecutrix by the appellant. See also Joy Ngozi Ezeilo, Women, Law \& Human Rights: Global and National Perspectives, op. cit., p. 121.

${ }^{45}$ Section 361 of the Act thereof.

${ }^{46}$ See section $222 \mathrm{~A}$ and $222 \mathrm{~B}$ thereof.

${ }^{47}$ Criminal Code, section 360.

${ }^{48} \mathrm{Ibid}$, section 216.

${ }^{49}$ CEDAW, Article 16(1)(e) and the Protocol to the African Charter on Human and Peoples' Rights on the Rights of Women in Africa 2003, Article 14.

${ }^{50}$ Criminal Code, section 230.

${ }^{51}$ Cap. P3, Laws of the Federation of Nigeria, 2004.

${ }^{52}$ See for instance, section 282 of the Penal Code which protects women against rape.

${ }^{53} \mathrm{Ibid}$, section 55(1)(d). It is worthy of note that section 19 of the Violence Against Persons (Prohibition) Act (VAPP Act) 2015 prohibits spousal battery and goes further in its section 45(2) to asset that the provisions of VAPP Act would supersede 
Such requirement, it submitted, is inconsistent with the obligation stipulated under CEDAW and the 1995 Beijing Declaration and Platform for Action ${ }^{54}$ whereby State parties are enjoined to condemn all forms of violence against women and not to invoke any custom, tradition or religious considerations to avoid their responsibility regarding such elimination.

Moreover, States are required to adopt all "appropriate measures, including legislation, to modify or abolish existing laws, regulations, customs and practices which constitute discrimination against women; as well as repeal all national penal provisions which constitute discrimination against women." ${ }^{, 55}$ It is therefore suggested that the provision of section 55 (1)(d) should be expunged from the statute book as it is not only discriminatory but also humiliating on the part of the wife, who is considered as a mere "housemate" or a "child of the marriage"by such treatment rather than an equal partner in the relationship. ${ }^{56}$

\subsection{Marriage Act $^{57}$}

The statute regulates statutory marriages in Nigeria. Unlike CEDAW and the Protocol to the African Charter on the Rights of Women in Africa, ${ }^{58}$ the legislation does not specify the minimum age of marriage for women, though it penalises marriages with a minor without obtaining the relevant parental consent. ${ }^{59}$ In this respect, section 18 of the Marriage Act suggests that the requisite parental consent is that of the father unless the latter is dead or of unsound mind or outside Nigeria before the consent of the mother is required. The implication of this is that the consent of a mother only becomes necessary in the occurrence of the specified circumstances. This requirement is discriminatory and contradicts the stipulation of Article 16(1)(d) of $\mathrm{CEDAW}^{60}$ as well as reflects ourpatriarchal society which views a child as belonging more to the father than the mother.

\subsection{The Child's Right Act ${ }^{61}$}

This law, which remains the primary legislation for the protection of the rights of children in Nigeria, came on the heels of Nigeria's ratification of the UN Convention on the Rights of the Child and the African Charter on the Rights and Welfare of the Child in July $1990 .{ }^{62} \mathrm{~A}$ child under the Act is a person under the age of eighteen years. ${ }^{63}$ It is worthy of note that the adoption by the General Assembly of the United Nations' Convention on the Rights of the Child (CRC) on 20 November1989 marked the beginning of attempts by the global community to provide legal recognition and protection for the rights of children, though the subject matter had been on the global agenda since shortly after the First World War. ${ }^{64}$

It has been argued that the 1990 African Charter on the Rights and Welfare of the Child was born out of the feeling by African member-states that the CRC missed significant socio-cultural and economic realities of the African experience. ${ }^{65}$ This is not to say that the Charter is opposed to the CRC.

the provisions of the principal criminal legislation (i.e. Criminal Code, Penal Code and Criminal Procedure Code) that deal with similar offences. But in view of the fact that the VAPP Act has not been domesticated in the northern States of Nigeria, it is doubtful if the Act's criminalisation of spousal battery can affect or nullify the applicability of section 55(1)(d) of the Penal Code. Even the Jigawa State Domestic Violence and other Related Matters Law No. 6 of 2006 allows the chastisement of a wife by the husband as a "correctional measure" if it is in accordance with the personal law of the husband to bring her to "order,"-section 2(v) thereof.

${ }^{54}$ See paragraphs 29 and 31 thereof.

${ }_{56}^{55}$ CEDAW, Article 2 (f) and (g).

${ }^{56}$ See CEDAW, Article 7; Declaration on the Elimination of Violence against Women (DEVAW) 1993, Articles 2 and 4; and Protocol to the African Charter on Human and Peoples' Rights on the Rights of Women in Africa 2003, Article 6.

${ }^{57}$ Cap. M6, Laws of the Federation of Nigeria, 2004.

${ }^{58}$ See Article 6(b) of the Protocol.

${ }^{59}$ Marriage Act, section 48.

${ }^{60}$ It states thus: 'States Parties shall take all appropriate measures to eliminate discrimination against women in all matters relating to marriage and family relations and in particular shall ensure, on a basis of equality of men and women: (d) [t]he same rights and responsibilities as parents, irrespective of their marital status, in matters relating to their children...'

${ }^{61}$ Cap. C50, Laws of the Federation of Nigeria, 2004.

${ }^{62} \mathrm{OAU}$ Doc.CAB/LEG/24.9/49.The Charter entered into force in November 1999.

${ }^{63}$ Child's Rights Act, op. cit., section 277.

${ }^{64}$ Dejo Olowu, "Protecting Children's Rights in Africa: A Critique of the African Charter on the Rights and Welfare of the Child," (2002) 10 The International Journal of Children's Rights, p.127.

${ }^{65}$ See generally F. Viljoen, "The African Charter on the Rights and Welfare of the Child," in C. J. Davel (ed.), Introduction to Child Law in South Africa (Lansdowne: Juta \& Co Ltd, 2000). 
On the contrary, the two pieces of instruments are complementary and both provide the framework through which children and their welfare are increasingly discussed in Africa. ${ }^{66}$ Perhaps with a possible intention of discouraging forced early girl child marriage, the Act boldly nullifies such practice irrespective of whether the child consents to it or not $^{67}$ and consequently imposes criminal sanction on the husband of a minor, or a person to whom she is betrothed or the promoter of such girl-child marriage ${ }^{68}$ Sexual relationship with or without the consent of the child ${ }^{69}$ and other forms of prostitution, sexual abuse, exploitation of a child as well as recruitment of children into the armed forces are similarly penalised under the Act. ${ }^{70}$ As a matter of fact, the right of a girl-child to education cannot be truncated by reason of pregnancy as she is given an opportunity of completing her education after delivery of the baby, on the basis of her individual ability. ${ }^{71}$

It is rather unfortunate that not every State of the Federation has domesticated this statute as a State legislation. ${ }^{72}$ The adoption of this law by States is essential as child matters come within the residual list in the 1999 Constitution, which gives States the prerogative to legislate on the subject matter. Though marriage comes within the exclusive legislative list, over which the Federal Government has power to legislate on, yet in Nigeria, it is an obvious fact that generally, marriages are governed by statutory law, customary law and Islamic law. Child-marriages are usually conducted under both customary law and Islamic law, thereby leaving the Federal Government, which regulates statutory marriage, powerless in the circumstances. ${ }^{73}$

In addition, even in States where the CRA has been domesticated, there are variations regarding the definition of a "child."Some States have reduced the "eighteen years" stipulated under the CRA. ${ }^{74}$ For instance, Akwa Ibom and Cross River States define a "child" as a person of sixteen years and below. ${ }^{75}$ On the other hand, Jigawa State defines a child for purposes of marriage not by age but by puberty. ${ }^{76}$

${ }^{66}$ Dejo Olowu, "Protecting Children's Rights in Africa: A Critique of the African Charter on the Rights and Welfare of the
Child," op. cit., p. 128.
${ }^{67}$ Child's Right Act, 2003 , section 21 . Notwithstanding the criminalisation of child marriage, it is submitted that there is no
known reported case of any conviction of a person for this offence in the Federal Capital Territory, Abuja where the Act is
operational or in other States of the federation where the Act has been domesticated, despite the fact that a number of
children continue to be given out in marriages at tender ages in some parts on Nigeria. See Cheluchi Onyemelukwe,
"Intersections of Violence against Women and Health: Implications for Health Law and Policy in Nigeria," (2016) 22 (3)
William \& Mary Journal of Women and the Law, 609 at 620 .
${ }^{68} \mathrm{Child}$ 's Right Act, section 23 .
${ }^{69} \mathrm{Ibid}$, section 31 .
${ }^{70} \mathrm{Ibid}$, sections $28,29,30,32,33$ and 34 .
${ }_{71}^{71} \mathrm{Ibid}$, section 15 (5).
${ }^{72}$ About twenty-four States, out of the thirty-six States of the Federation, have adopted the legislation as State laws. On the other hand, twelve States, eleven of them in the northern part of the country, have not enacted the law in their respective domains. See UN Children's Fund (UNICEF), UNICEF Nigeria-Fact Sheet: Child Rights Legislation in Nigeria 2 (April 2011). Retrieved from http://www.unicef.org/nigeria/Child_rights_legislslation_in_Nigeria.pdf .Accessed on 29 November 2011. See also See Funke Adekoya, SAN, Women, Widows, Orphans, Children \& the Less Privileged: Their Rights and Protection under the Law. Being a Paper Presented at the Chief Judge's Annual Seminar/Workshop, Held at the International Events Centre (The Dome), Akure, on 4 October 2017, p. 16.See also George Opara, "Senate moves to domesticate Child Rights Act In 13 States," (26 May 2017)The Guardian. Retrieved from <https:// guardian.ng/news/senate-moves-todomesticate-child-rights-act-in-13-states/>.Accessed on 12 September 2017. See also See also Cheluchi Onyemelukwe, "Intersections of Violence against Women and Health: Implications for Health Law and Policy in Nigeria," (2016) 22 (3) William \& Mary Journal of Women and the Law, 609 at 620-621.

${ }^{73}$ See Item 61 on the Exclusive Legislative List, Part 1, Second Schedule to the Constitution of the Federal Republic of Nigeria, 1999 (as Amended). See Also Tim S. Braimah, "Child Marriage in Northern Nigeria: Section 61 of Part 1 of the 1999 Constitution and the Protection of Children against Child Marriage," (2014) 14 African Human Rights Law Journal, 474 at $483-484$.

${ }_{75}^{74}$ Child's Rights Act, op. cit., section 277.

${ }^{75}$ See Commission on the Rights of the Child, Consideration of Reports Submitted by States Parties under Article 44 of the Convention, 26 U.N. Doc. CRC/C/NGA/CO/3-4 (June 11, 2010), cited in Cheluchi Onyemelukwe, "Intersections of Violence against Women and Health: Implications for Health Law and Policy in Nigeria," op. cit., p. 621.

${ }^{76}$ See section 15(1) of the repealed Jigawa State Child's Rights Law, which abolished child marriage and went further in its section 2(1) to construe a child as a person below the age of puberty. The said section 2 of the Jigawa State CRL defined "puberty" as the "age which a person is physically and psychologically capable of consummating a marriage." As a matter of fact, section 27 of the Niger State Child's Rights Law 2010, which is also one of the Northern States of Nigeria, stipulates that where there is a conflict regarding questions of Islamic law with any provisions of the Child's Rights Law, Islamic 
In other words, a girl-child under the stated ages or phase of life in these States can be married under the customary or Islamic laws. Thus, a significant number of female children continue to be married off in some parts of Nigeria. ${ }^{77}$ It is also disturbing that such marriages to female minors are at times perpetuated by government officials ${ }^{78}$ and are either impliedly recognised by them ${ }^{79}$ or encouraged by their religious organisations. ${ }^{80}$

Apart from religious and cultural factors, poverty also plays a vital function in encouraging child marriages. Girls who are forced into marriages at tender ages tend to come from poor family backgrounds and with low levels of education. ${ }^{81}$ There are reported cases of fathers using their female children as collateral securities to obtain monetary from creditors. Sometimes those girls are forced into marriages ("money woman marriages")with the creditors where their fathers failed to repay the loan. ${ }^{82}$ Nonetheless, regardless of the contributory factors that may promote child marriage, the fact still remains that the practice has its consequential health implications like death at child birth, complications during child birth, vagino-vesico fistula (VVF) and increased risk of cervical cancer. ${ }^{83}$ This is in addition to increasein infant morbidity and mortality rate. ${ }^{84}$

\subsection{Trafficking in Persons (Prohibition) Law Enforcement and Administration Act 2003 (as amended) ${ }^{85}$}

In its attempts to protect the rights of women, the Act prohibits all forms of sexual exploitation of women, including seduction, pornography, defilement, indecent assault, rape, kidnapping, abduction and trafficking for purposes of prostitution, slavery ${ }^{86}$ or forced recruitment into armed conflicts. ${ }^{87}$

personal law will supersede. See Enyinna S. Nwauche, “Child marriage in Nigeria: (II) legal and (un)constitutional?" (2015) 15 African Human Rights Law Journal, p. 428.

${ }^{77}$ See Child Marriage around the World: Nigeria, Girls Not Brides. Retrieved from http://www.girlsnotbrides.org/childmarriage/nigeria . Also http://www.perma.cc/9Y5P-GUN7, where it was alleged that an estimated 43\% of females in Nigeria are married off before the attainment of eighteen years of age.

${ }^{78}$ Afua Hirsch, "Nigerian Senator Who 'Married Girl of 13' Accused of Breaking Child's Rights Act," (25 July 2013) The Guardian. Retrieved from http://www.theguardian.com/world/2013/jul/25/nigeria-senator-accused -child-bride . Accessed 30 July 2013.

${ }^{79}$ See Cheluchi Onyemelukwe, "Nigeria: The Brouhaha...and Why It Should Continue," (Lagos, 30 July 2013) This Day Live. Retrieved from https://allafrica.com/stories/201307300574.html . Accessed on 3 January 2020.

${ }^{80}$ For instances, following a strong public condemnation of the marriage of Senator Sani Yerima to a thirteen year old Egyptian girl, including a call by the National Human Rights Commission for the intervention of the National Assembly in the matter, the Supreme Council for Sharia in Nigeria instituted an action at the Federal High Court, Abuja against the Federal Government and the National Assembly, seeking inter alia for the nullification of some sections of the CRA, including section 21 which prohibits the marriage of a girl child below the age of eighteen years as such was in conflict with the Islam and the practice of Sharia as well as the private and family life of the husband which could be invaded or interfered with if the provisions of the CRA sought to be abolished are allowed to remain. See Kingsley Nwezeh, "Nigeria: YerimaSharia Council Drags FG, National Assembly to Court," (Lagos, 4 June 2010) This Day. Available at http://www.allafrica.com/stories/201006071572.html. Accessed on 22 December 2019. See also Enyinna S. Nwauche, "Child marriage in Nigeria: (II) legal and (un)constitutional?" (2015) 15 African Human Rights Law Journal, p. 429.

${ }^{81}$ Nawal M. Nour, "Health Consequences of Child Marriage in Africa," (2006) 12 (11) Emerging Infectious Diseases, 1645.

${ }^{82}$ This is common among the Becheve tribe of Obanliku Local Government Area of Cross River State, Nigeria. See "NGO sues Cross River State government over use of women as loan collateral by Becheve people", (10 November 2018) Pulse. Available at https://www.pulse.ng/news/local/money-woman-ngo-sues-cross-river-state-government-over-use-of-women-asloan/b9j927z. Accessed on 3 January 2020.

${ }^{83}$ Nawal M. Nour, "Health Consequences of Child Marriage in Africa," (2006) 12 (11) Emerging Infectious Diseases, op. cit, 1646.

${ }^{84}$ Cheluchi Onyemelukwe, "Intersections of Violence against Women and Health: Implications for Health Law and Policy in Nigeria," op. cit., p. 620.

${ }^{85}$ Act No. 24 of 2003. See Cap. T23, Laws of the Federation of Nigeria, 2004. The Act came into force on 14 July 2003.

${ }^{86}$ In a recent video that went vial, a Nigerian woman, Omolola Ajayi, narrated how she was trafficked to Lebanon and sold into slavery. It took the efforts of the Nigerians in Diaspora Commission (NIDOM) and the federal government for her to be rescued and returned home- see Adelani Adepegba, "FG rescues 23-year-old Nigerian lady trafficked to Lebanon," (Lagos, 13 January 2020) The Punch. Available at https://punchng.com/fg-rescues-23-year-old-nigerian-lady-trafficked-to-lebanon/. Accessed on 17 January 2020.

${ }^{87} \mathrm{Ibid}$, sections 11-26. As a matter of fact, with a possible aim of fight human trafficking and discouraging sexual exploitation of women, NAPTIP has opened a Federal Government's Sexual Offenders Register where names and pictures of convicted sexual offenders could be registered and published. As at December 2019, it was reported that the names of five male convicts jailed in 2019 by various courts for various sexual offences were registered in the register. See Olaleye Aluko, "Nigerians on Sex Offenders' List Risk Travel Ban," The Punch (Lagos, 14 December 2019). Available at 24 
It further asserts that a trafficked person shall not be subjected to discriminatory treatment on grounds of race, colour, gender, sex, age, language, religion, political or other opinion cultural beliefs or practices, national ethnic or social origin, property, birth or other status including his/her status as a victim of trafficking or having worked in the sex industry. ${ }^{88}$ It is heart-warming that a victim of trafficking who may have suffered physical, economic, psychological and social damage as a result of his or her exploitation by a trafficker is entitled to compensation, restitution and recovery derivable from the assets, if any, of a convicted trafficker forfeited and paid to the Victims of Trafficking Trust Fund. ${ }^{89}$ The implementation of the Act is conferred on the National Agency for the Protection of Traffic in Persons and other Related Matters (NAPTIP). ${ }^{90}$

\subsection{Violence Against Persons (Prohibition) Act, 2015(VAPP Act) ${ }^{91}$}

This statute is the most recent and encompassing law on violence against persons, including women, in Nigeria. ${ }^{92}$ The VAPP Act can be said to be a step towards fulfilling Nigeria's global responsibilities as required under CEDAW and the Protocol to the African Charter on Human and Peoples' Rights on the Rights of Women in Africa 2003. It has been suggested that the legislation has to some extent filled the gaps that existed regarding the protection of women as well as provided remedies to women who had suffered various harms by reason of violence done to them as a result of their gender. $^{93}$

In an attempt to provide a solid footing for operational and synchronised legal framework against violence against women, VAPP Actinter alia, addresses issues like domestic/intimate partner violence such as spousal battery, ${ }^{94}$ rape,${ }^{95}$ incest, ${ }^{96}$ forceful ejection from home, ${ }^{97}$ physical abuse, emotional or psychological abuse, ${ }^{98}$ and attack with harmful substances, such as acid-bath, ${ }^{99}$ female genital mutilation, ${ }^{100}$ harmful widowhood and traditional practices,${ }^{101}$ coerced financial dependence or economic abuse, ${ }^{102}$ and abandonment of spouse and children. ${ }^{103}$ Each of the offences criminalised under the Act attracts penalties. Aside from the imprisonment terms prescribed for rape, the law also makes provision for payment of compensation to the victim ${ }^{104}$ and the creation of convicted sexual offenders' register which should be made accessible to the public. ${ }^{105}$

https://punchng.com/nigerians-on-sex-offenders-list-risk-travel-ban/ .Accessed on 15 December 2019 . See also Olaleye Aluko, "Employers should check sexual offenders' register to know the people they employ-NAPTIP DG," (Lagos, 24 December 2019)The Punch. Available at https://punchng.com/employers-should-check-sexual-offenders-register-to-knowthe-people-they-employ-naptip-dg/. Accessed on 24 December 2019.

${ }^{88}$ NATIP Act, section 50(a).

${ }^{89}$ See sections 35-48 of the Act. See also Trafficking in Persons (Establishment of the Board of Victims of Trafficking Trust Fund) Regulations, S. 1.3 of 2008, paragraph 3.

${ }^{90}$ NATIP Act, sections $1,4,5$ and 6.

${ }^{91}$ The Act was signed into law on 25 May 2015 after over ten years in the legislative process.

92 Cheluchi Onyemelukwe, "Legislating on Violence against Women: A Critical Analysis of Nigeria's Recent Violence against Persons (Prohibition) Act, 2015," (2016) 5(2) Depaul Journal of Women, Gender and the Law, p. 4. Retrieved fromhttp://via.liabrary.depaul.edu/jwgl/vol5/iss $2 / 3$.

Accessed on 12 November 2017.

${ }^{93}$ Ibid, p. 7.

${ }^{94}$ The VAPP Act 2015 defines "spousal battery" as "the intentional and unlawful use of force or violence upon a person, including the unlawful touching, beating or striking of another person against his or her will with the intention of causing bodily harm to that person"- sections 19 and 46.

${ }^{95} \mathrm{Ibid}$, section 1.

${ }^{96} \mathrm{Ibid}$, section 25 .

${ }^{97} \mathrm{Ibid}$, section 9.

${ }^{98} \mathrm{Ibid}$, section 14.

${ }^{99} \mathrm{Ibid}$, sections 21 and 22.

${ }^{100}$ Ibid, section 6.

${ }^{101} \mathrm{Ibid}$, section 15 and 20.

${ }^{102} \mathrm{Ibid}$, section 12.

${ }^{103} \mathrm{Ibid}$, section 16.

${ }^{104} \mathrm{Ibid}$, section 1(3). It is submitted further that victims of violence contemplated under the Act are further entitled to all the justiciable rights provided for under chapter 4 of the 1999 Constitution of the Federal Republic of Nigeria (as amended) as well as the rights and remedies recognised under global human rights instrument to which Nigeria is a party to-see section 38(1) of the VAPP Act 2015.

${ }^{105}$ Ibid, section 1(4). 
The definition of rape has been expanded under VAPP Act as the term is no longer restricted to penile-vagina penetration ${ }^{106}$ which is customary under the Criminal and Penal Code, but it covers the penetration of the "anus or mouth of another person with any other part of his or her body or anything else" "107 without the consent of the victim ${ }^{108}$ or where the consent was fraudulently obtained or was secured by force or use of any substance or addictive which is capable of affecting the will of the person. ${ }^{109}$ What constitutes "sexual organ" for the purpose of the offence of rape under the Act has given room to speculations. In this respect, Ekhator ${ }^{110}$ aligning with Ukhuegbe ${ }^{111}$ have argued that with the stance of the Act concerning the offence of rape, a kiss obtained by force may amount to a rape if "the tongue sticks into the mouth of an unconsenting person." Also putting one's mouth or hand into the vagina of a woman or girl without her consent is capable of securing conviction for the offence of rape. ${ }^{112}$

Furthermore, there is contention regarding whether the Act penalises spousal rape. ${ }^{113}$ This is because section 1 begins the definition of a rapist with the term "a person" without any limitation. Does such term cover a marital partner? While Onyemelukwe posits that spousal rape has been criminalised under the Act and that in the absence of consent, either couple can be penalised under the Act, ${ }^{114}$ Ukhuegbe has argued that although marital rape has not been specifically acknowledged under the act, yet it is likely for a husband to be held accountable for the offence under the Act. ${ }^{15}$ However, the position adopted by the present writer finds support with that of Ekhator to the effect that regardless of the expansive construction of the concept of rape under the Act, only the court with time will assist in removing the veil regarding whether spousal rape is penalised under the Act. ${ }^{116}$

Statutes on domestic violence are also available in some few States, such as Lagos, ${ }^{117}$ Cross River, ${ }^{118}$ Ekiti, ${ }^{119}$ Jigawa, ${ }^{120}$ Ebonyi, ${ }^{121}$ and Oyo. ${ }^{122}$

106 Cheluchi Onyemelukwe, "Legislating on Violence Against Women: A Critical Analysis of Nigeria's Recent Violence Against Persons (Prohibition) Act, 2015," (2016) 5(2) DePaul Journal of Women, Gender and the Law, p. 26. Available at http://via.library.depaul.edu/jwgl/vol5/iss2/3. Accessed on 23 September 2018.

${ }^{107}$ Ibid, section 1(1)(a).

${ }^{108}$ It is submitted that unlike the position under the Criminal Code and Penal Code where only a woman or girl could be a rape victim, the position under the extant VAPP Act 2015 reveals that a man can be guilty of raping a fellow male by virtue of section 1(1).

${ }^{109}$ The VAPP Act 2015, section 1(1)(b)(c).

${ }^{110}$ Eghosa Ekhator, "Protection and Promotion of Women's Rights in Nigeria: Constraints and Prospects" (14 October 2018), p. 8. Available at https://www.researchgate.net/publication/328276496. Accessed on 16 December 2019.

${ }^{111}$ Solomon Ukhuegbe, "Recent Legislation against Sexual and Gender-Based Violence in Nigeria," (2015) 16(1) University of Benin Law Journal, p.304.

${ }^{112}$ See Deji Lambo, "Sad tales of rape victims still left to lick their tears," (Lagos, 31 December 2019), The Punch. Available at https://punchng.com/sad-tales-of-rape-vctims-still-left-to-lick-their-tears/ . Accessed on 31 December 2019, where it was reported that one Adegboyega Adenekan, a supervisor at Chrisland School, was convicted of rape by Hon. Justice Sybil Nwaka of the Lagos State Special Offences Court and sentenced to 60 years imprisonment without an option of fine for putting his mouth and hand into the private part of two female pupils.

${ }^{113}$ Under the definition of rape stated in section 357 of the Criminal Code Act, Cap. C38, Laws of the Federation of Nigeria 2004, carnal relationship which occurs between husband and wife is not regarded as rape regardless of the absent of consent by either party. This is not unconnected with the recognised customary and religious acceptance, which is in line with the English common criminal law principle as it is assumed that the wife has given her implied general consent to her husband to have sexual intercourse with her during the subsistence of the marriage and that she cannot unilaterally withdraw from it. See Eghosa Ekhator, "Women and the Law in Nigeria: A Reappraisal" (2015) 16(2) Journal of International Women's Studies, p. 288; Kaine Agary, "Marital rape under Nigerian law," (3 September 2017) The Punch. Available at https://punchng.com/marital-rape-under-nigerian-law/. Accessed on 28 December 2019. However, where the marriage has been dissolved or a competent court has made an order of separation with a clause stating that the wife was no longer bound to cohabit with her husband, the implied consent would be deemed to have been revoked and while the order subsists, any sexual relationship with the woman by the husband without her consent would be regarded as a rape- see $R$. v. Clarke (1949) 33 Cr. App. R. 216.

${ }^{114}$ Cheluchi Onyemelukwe, "Legislating on Violence Against Women: A Critical Analysis of Nigeria's Recent Violence Against Persons (Prohibition) Act, 2015," (2016) 5(2) DePaul Journal of Women, Gender and the Law, pp. 26-27. Available at http://via.library.depaul.edu/jwgl/vol5/iss2/3. Accessed on 23 September 2018.

${ }^{115}$ Solomon Ukhuegbe, "Recent Legislation against Sexual and Gender-Based Violence in Nigeria," op. cit, p. 307.

${ }^{116}$ Eghosa Ekhator, "Protection and Promotion of Women's Rights in Nigeria: Constraints and Prospects," op cit, p. 9.

${ }^{117}$ Protection Against Domestic Violence Law No. 15 of 2007.

${ }^{118}$ Domestic Violence and Maltreatment of Widows (Prohibition) Law No. 6 of 2005.

${ }^{119}$ Gender-Based Violence (Prohibition) Law No. 21 of 2011. 
With respect to the Cross River State law on the issue, the subjection of women to any form of unwholesome treatment or domestic violence ${ }^{123}$ as well as subjecting a widow to any form of maltreatment and/or obnoxious traditions ${ }^{124}$ are proscribed. The law prescribes criminal sanctions for violators. ${ }^{125}$

\subsection{Cybercrimes (Prohibition, Prevention, Etc) Act 2015}

Though the Act can be described as a comprehensive regulatory framework for the prohibition and prevention of cybercrimes in Nigeria, yet its provisions can be relied upon for the protection of the dignity of a woman or girl. For instance, section 24(1) of the Act prohibits cyber stalking. It punishes any person who deliberately sends a "message or other matter" electronically which is capable of being "grossly offensive, pornographic or of an indecent, obscene or menacing character" with imprisonment term of three years or a fine of seven million Naira or both such fine and imprisonment. The Federal High Court Ado Ekiti, relying on the authority of the section of the statute has recently convicted one Ayan Olubunmi for publishing the nude pictures of his estranged lover who had informed him that she was no longer interested in the relationship. ${ }^{126}$ According to the learned trial Judge, I find this act of the convict highly disgraceful, very despicable and barbaric to say the least. He has behaved true to the saying that hell knows no fury than a lover's scorn. I must say that the defendant who has a wife and children at home could find it easy to demean and embarrass a woman who was having an amorous affair with him....It is an act of meanness to attempt to, if he has not already tarnished the image and reputation of Asare Monica..., The world has become a global village with the emergence of the social media. Who knows who would have seen the nude pictures? ${ }^{127}$

Indisputably, both the provision of the statute and the attitude adopted by the court in the instant case are commendable. However, it is suggested that as a form of compensating a victim of cyber stalking, there is need to amend the law by making provision for payment of monetary compensation to a victim whose image has been tarnished by the irresponsible and thoughtless acts of the defendant.

\section{Domestic Policy Frameworks for Women's Rights in Nigeria}

There are a number of governmental policies fashioned out to protect the rights of women and girls in Nigeria. These include but not limited to the National Reproductive Health Policy ${ }^{128}$ National Policy and Plan of Action for the Elimination of Female Genital mutilation in Nigeria 2013-2017, National Strategic Framework for the Elimination of Obstetrics Fistula in Nigeria 2019-2023, National Gender Policy (NGP), National Policy on the Sexual and Reproductive Health and Rights of Persons with Disability (with emphasis on Women and Girls), among others. ${ }^{129}$ However, for the purpose of this section of the article, I will brief examine only one of such policies, National Gender Policy (NGP) of the Federal Republic of Nigeria.

\subsection{National Gender Policy of the Federal Republic of Nigeria 2006}

The National Gender Policy (NGP) of the Federal Republic of Nigeria was established in 2006 by the Ministry of Women Affairs and Social Development. ${ }^{130}$ The National Policy is aligned with relevant regional and international protocols and instruments aimed at eliminating "gender discriminations, ensuring equality and human rights.",131

${ }^{120}$ Domestic Violence and Other Related Matters Law No. 6 of 2006.

${ }^{121}$ Protection Against Domestic Violence and Related Matters Law No. 3 of 2005.

${ }^{122}$ Violence Against Women Law No. 9 of 2016.

${ }^{123}$ Domestic Violence and Maltreatment of Widows (Prohibition) Law, op. cit., section 1.

${ }^{124} \mathrm{Ibid}$, section 2 . Section 3 goes further to itemise some forms of maltreatment or obnoxious traditions against widows.

${ }^{125}$ Ibid, section 3.

${ }^{126}$ See Attorney-General of the Federation v. Ayan Olubunmi, Charge No. FHC/AD/17C/2017 (unreported). The court sentenced the defendant to two years imprisonment and a fine of $\$ 500,000$.

${ }^{127}$ Ibid, per Hon. Justice Taiwo Taiwo, quoted in "Man Bags Two Years in Jail for Posting Ex-lover's Nude Pictures on Facebook," (Lagos, 24 October 2018), Sahara Reporter. Available at http://saharareporters.com/2018/10/24/man-bags-twoyears-jail-posting-ex-lovers-nude-pictures-facebook . See also Wale Odunsi, "Married man sent to prison for posting lover's nude photos online," (Lagos, 24 October 2018) Daily Post. Available at https://dailypost.ng/2018/10/24/married-man-sentprison-posting-lovers-nude-photos-online . Both accessed on 13 January 2020.

${ }^{128}$ This was approved in 2010 by the Federal Government with the objective of ensuring availability and access to total sexual reproductive health information and quality services. It has been revised recently in 2017.

${ }^{129}$ See "Nigeria: Govt Launches Eleven Policies on Reproductive Health, Others," (Lagos: 14 April 2019), Daily Trust. Available at https://allafrica.com/stories/201904240097.html. Accessed on 2 January 2020.

${ }^{130}$ National Gender Policy. Federal Ministry of Women Affairs and Social Development, 2006. Retrieved from http://www.aacoalition.org/national_policy_women.htm . Accessed on 27 April 2018.

${ }^{131}$ Such instruments include, but not limited to, the Beijing Platform for Action (BPfA), African Union Solemn Declaration for Gender Equality, African Protocol on People's Rights and the Rights of Women (APPRRW), the Convention on the 
However, bearing in mind the varying socio-economic and cultural backgrounds and developmental status of the 36 States of the Federation, the Policy allows each State to domesticate the NGP, while ensuring linkages with the National Gender Policy Framework (NGPF) through the Federal Ministry of Women Affairs and Social Development (FMWASD). For instance, in Jigawa State where the policy has been domesticated, ${ }^{132}$ in drafting the State gender policy, the needs and realities of the State, the Islamic value system and cultural norms of the people of Jigawa State were taken into consideration. ${ }^{133}$ Regarding the theoretical base of the JSGP, the document itself expressly admitted thus: Jigawa State seeks to pursue the gender affirmative action within the framework of Islamic Law and Jurisprudence, Islam being the religion and way of life of the vast majority of its people. The State adopts the Islamic philosophy of gender, which recognises the physiological and functional differences of males and females in society without discriminating between the two. This frame of reference accords with accepted norms and values of religion, and ensures equity, justice and fairness in all gender issues. ${ }^{134}$

Notwithstanding the noble ambition of the NGP, it is submitted that the policy not being a piece of legislation lacks a binding force on any person or authority. It will require, among other things, the political will of the government and the effective education of the populace to attain its worthy objectives and strategies. In addition, it is also necessary to facilitate the strengthening of mechanisms for enforcing laws that regulate and penalise discriminatory practices. This could be achieved through collaboration with and sensitising the legislature, the judiciary and other law enforcement agencies to uphold gender justice and gender equity principles. ${ }^{135}$

\section{Some Constraints to Effective Enjoyment of Women's Rights in Nigeria}

It is obvious that there has been a considerable volume of treaties, national laws and policy frameworks entered into or enacted by the Nigerian government at the various levels for the promotion of women's rights in the country. It is a common knowledge too that women still suffer some deprivations regardless of the existence of such legal and policy frameworks in the country. The section of the article examines some factors militating against effective enjoyment of women's rights in Nigeria.

\subsection{Patriarchal Nature of the Nigerian Society}

As earlier noted, Nigeria, like other African countries, is a highly patriarchal society, where men dominate all spheres of life and gender inequality is pronounced. Women are in subordinate positions, and male children are preferred over the female. ${ }^{136}$ To achieve gender equality and promote women's rights in the Nigerian society, it is vital that the government should provide men and women equal opportunities in decision-making and policy implementations, and not treat the female gender as belonging solely to the "kitchen...(the) living room and the other room." 137 This is also necessary at the local communities and the family units where the practice is predominant. As rightly noted by Akande: The history of Africa is replete with stories and legends of powerful women who exerted great influence in the political activities of their country. Powerful women who "ruled" the society and/or participated in a system of diffuse authority, fluid and informal leadership, shared rights of enforcement and a more or less stable balance of male and female power... 138

Such accomplishments by women underscore the fact that they have all it takes to actively participate in decision making and policy implementations in the Nigerian society.

\subsection{Cultural Practices}

Elimination of All Forms of Discrimination Against Women (CEDAW), etc. See the Foreword to the National Gender Policy and para. 2.1 thereof, ibid.

${ }^{132}$ See Jigawa State Gender Policy (JSGP) 2013.

${ }_{133}^{133} \mathrm{Ibid}$, Preamble.

${ }^{134}$ Ibid.

${ }^{135}$ Ibid, Paragraph 2.1(d), p. 11.

${ }^{136}$ Mojekwu v. Mojekwu (1997) 7 NWLR (Pt. 486) 144 where Niki Tobi, JCA (as he then was) strongly castigated the oli ekpe custom of Nnewi people of Anambra State which debarred women from inheriting landed property, in the following words, "....it is the monopoly of God to determine the sex of a baby and not the parents...Accordingly, for a custom or customary law to discriminate against a particular sex is to say the least an affront to the Almighty God himself. Let nobody do such a thing..."

${ }^{137}$ See BBC News-Africa, "Nigeria's President Buhari: My wife belongs in Kitchen," (14 October 2016) BBC NEWS. Retrieved from https://www.bbc.com/news/world-africa-37659863. Accessed on 30 December 2019.

${ }^{138}$ Jadesola Akande, "Women and the Law" in Akintunde O. Obilade (ed.) Women in Law (Southern University Law Center and Faculty of Law, University of Lagos, 1993), p. 15. 
This is closely associated with the patriarchal nature of the Nigerian society. There are several cultural practices which inhibit the rights of Nigerian women. These include, but not limited to such practices like polygamy, widowhood practices, female genital mutilation/female circumcision, levirate marriage, ${ }^{139}$ early child betrothal/marriage, inheritance and succession rights of the female child, etc. With respect to property inheritance right, some cultural practices prevent widows from sharing in their deceased husband's landed property as she is considered as one of the deceased's properties to be acquired by the husband's male relative. ${ }^{140} \mathrm{~A}$ female child is also under the Igbo customary law prevented from inheriting the father's property ${ }^{141}$ except she elects to remain unmarried in the father's compound to raise up children in the father's name. This practice is called nrachi or idebe and usually occurs where a man leaves behind female children without any male child. ${ }^{142}$

The rationale for not allowing female family members to inherit a family land may not be unconnected with the longestablished fear that if she is granted such succession right, it may result in surrendering family land to her prospective husband who naturally is not only a member of another family but also may belong to a distinct ethnic nationality. ${ }^{143}$ Notwithstanding the underlying principle for such practice, it is submitted that such discriminatory practice "only intended to protect the selfish perpetration of male dominance which is aimed at suppressing the right of the women folk in the given society." ${ }^{144}$ Thus, the impropriety of a custom of this nature which militates against women on grounds of "God's instituted gender differential" 145 deserves a strong and absolute condemnation.

Admittedly, the 1999 Constitution under its directives principles on Nigerian cultures asserts that the government should "protect, preserve and promote Nigerian cultures." 146 However, it is submitted that such cultures which should be encouraged by the Nigerian State should be such as "enhance human dignity and consistent" with not only the constitutional fundamental objectives ${ }^{147}$ but also with the fundamental rights enshrined in the 1999 Constitution ${ }^{148}$ and other global human rights instruments which uphold gender equality.

\subsection{Conservative Judicial Attitude}

As has been illustrated in the article, there have been numerous customary practices and laws which discriminate against women, yet the characterised conservative attitude of the Nigerian courts have sustained some of such practices which suppressed women's rights for a long time. ${ }^{149}$ Even in instances where the facts of the case clearly showed gender discrimination, which is seriously frowned at under the 1999 Constitution and numerous global and regional instruments, the court had instead based its decisions on the "repugnancy to natural justice, equity and good

\footnotetext{
${ }^{139}$ Under customary marriage, the death of the husband does not automatically terminate the marriage as the woman is subject to be inherited by another male member of the deceased husband's family. In the event that she wishes to remarry another person outside the husband's family, the widow or her family would be required to refund the dowry or bride price paid by the deceased husband on her head. See Joy Ngozi Ezeilo and Nkiru Nwadioke, "Women and Marriage: Legal and Social Dimensions," in Joy Ngozi Ezeilo and Josephine Edna Alumanah (eds.), Bride Price and the Implications for Women's Rights in Nigeria (Women Aid Collective, 2008), p. 3.

${ }^{140}$ Suberu v. Sunmonu (1957) 2 FSC 31 at 33; Nzerianya v. Okagbue (1963) 1 All NLR 352; Akinnubi v. Akinnubi (1997) 2 NWLR (Pt. 486) 144. But in the latter cases of Nzekwu v. Nzekwu (1989) 2 NWLR (Pt. 104) 373, (1989) 3 SCNJ 157 and Anekwe v. Nweke (2014) All FWLR (Pt. 739) 1154 at 1178-1179, the Nigerian Supreme Court maintained that a widow had the right of possession of the deceased husband's property and that no member of her husband's family had a right to dispose her of it even though she had no male child for her deceased husband. In the words of Ogunbiyi, JSC, “...For a widow of a man to be thrown out of her matrimonial home, where she had lived all her life with her late husband and children by her late husband's brothers on the ground that she had no male child, is indeed very barbaric, worrying and flesh skinning."

${ }^{141}$ Uboma v. Ibeneme (1967) ENLR 251. However, under the Hausa custom, a woman is entitled to inherit from either of her parents' estate. See Ayodele V. Atsenuwa, "Women's Rights within the Family Context: Law and Practice," in Akintunde O. Obilade (ed.) Women in Law (Southern University Law Center and Faculty of Law, University of Lagos, 1993), p. 126; see also A. V. Oyajobi, "Better Protection for Women and Children under the Law," in Kalu and Yemi Osinbajo (eds.) Women and Children under the Law, (Federal Ministry of Justice Law Review Series, 1989), p. 33.

${ }^{142}$ Muojekwu v. Ejikeme (2000) 5 NWLR (Pt. 657) 402.

143 See E. I. Nwogugu, "Emancipation of Female Rights to Intestate Succession under Igbo Customary Law," (2014) 12 The Nigerian Juridical Review, p. 10.

${ }^{144}$ Anekwe v. Nweke (2014) All FWLR (Pt. 739) 1154 at 1179, per Ogunbiyi, JSC.

${ }^{145}$ Ibid.

${ }^{146}$ See section 21(a) of the 1999 Constitution of the Federal Republic of Nigeria (as amended).

${ }^{147}$ Ibid.

${ }^{148}$ See generally the provisions of Chapter Four of the 1999 Constitution.

${ }^{149}$ See for instance, Akinnubi v. Akinnubi (1997) 2 NWLR (Pt. 486) 144.
} 
conscience"test rather than on the constitutional provisions against discrimination. ${ }^{150}$ The case of Mojekwu $v$. $M o j e k w u^{151}$ however marked a turning point regarding recognition of women's right to inheritance of family landed property. Subsequent cases like Amusan v. Olawuni ${ }^{152}$ and Asika v. Atuanya ${ }^{153}$ have similarly upheld the rights of female members of the family to inherit family landed properties like their male siblings. Specifically, in Ukeje v. Ukeje $^{154}$ the Supreme Court nullified the Igbo customary law which prevented daughters from inheriting their fathers' estates on the ground that such discriminatory customary practice was contrary to the provisions of section 42(1) (a)and (2) of the 1999 Constitution. ${ }^{155}$

\subsection{Non-domestication or Ratification of International Instruments and National Laws on Women's Rights}

Some international instruments like the Convention on the Nationality of Married Women ${ }^{156}$ and the Convention on the Political Rights of Women ${ }^{157}$ have not been ratified by the Nigerian government while other ratified instruments such as the CEDAW and Protocol on the African Charter on the Rights of Women have not been domesticated in Nigeria and consequently lack the force of law as required under section 12 of the 1999 Constitution. The implication of this is that regardless of how beneficial to the country or the citizenry such international or regional instruments may be, they remain unenforceable untilthey are ratified and/or are domesticated by the National Assembly. ${ }^{158}$

In addition, some national laws like the VAPP Act and the Child's Right Act do not apply to the entire country, but are limited to the Federal Capital Territory. ${ }^{159}$ The reason for this is because criminal law and child's right issues come within the residual list in the 1999 Constitution of the Federal Republic of Nigeria over which the States Houses of Assembly have the legislative competence to legislate upon. ${ }^{160}$ The doctrine of "operation cover the field" would have been applicable had the subject matters been on the concurrent legislative lists. ${ }^{161}$ It is submitted therefore, that if these national laws are domesticated appropriately, they would have the potentials of providing homogeneous overarching safeguards for the rights of women and girls in the country.

\subsection{Extant Discriminatory Laws Against Women}

The article has highlighted some sections in our statute books which promote discriminatory practices against women such as sections $118(\mathrm{~g}), 122,123,124$ and 127 of the Police Act. Others include, but not limited to sections 55(1) of the Penal Code which encourages wife chastisement; sections $34(1),{ }^{162} 55(1)^{163}$ and $56(1)^{164}$ of the Labour Act. ${ }^{165}$ It is a welcome development however, that the courts have struck down some of the extant discriminatory provisions in our laws and render the null, void and unconstitutional. ${ }^{166}$

\footnotetext{
${ }^{150}$ Nzekwu v. Nzekwu (2002) 11 NWLR (Pt. 723) 196; Uke v. Iro (1989) 2 NWLR (Pt. 104) 373. But in Mojekwu v. Mojekwu (1997) 7 NWLR (Pt. 512) 238, the court relied on both the doctrine of repugnancy to natural justice, equity and good conscience test as well as the constitutionally recognised right to freedom from discrimination.

${ }^{151}$ Ibid. the case later got to the Supreme Court in Mojekwu v. Iwuchukwu (2004) All FWLR (Pt. 211) 1406. See also Osita Nnamani Osita, Human Rights Law and Practice in Nigeria (Second Edition, Enugu: Snaap Press Ltd) 389.

152 (2002) FWLR (Pt. 118) 1385 at 1402

${ }^{153}$ (2008) 7 NWLR (1117) 484 at 518.

154 (2014) All FWLR (Pt. 730) 1323, (2014) 11 NWLR (Pt. 1418) 384.

${ }^{155}$ Ibid, pp. 1341, 1343.

156309 U.N.T.S. 65. Adopted on 29 January 1957, entered into force on 11 August 1958. A text copy is available at http://hrlibrary.umn.edu/instree/w1cnmw.html. Accessed on 14 January 2020.

${ }_{157}^{157}$ Adopted on 20 December 1952, entered into force on 7 July 1954.

${ }^{158}$ Abacha v. Fawehinmi (2000) FWLR (Pt. 4) 533 at 653.

${ }^{159}$ See for an example sections 27 and 47 of the Violence against Persons (Prohibition) Act 2015.

${ }^{160}$ See section 4(7) of the 199 Constitution.

${ }^{161}$ Section 4(5) of the 1999 Constitution.

162 The section states that the wife or wives and children below 16 years of age are allowed to accompany a male employee in the public service to his place of posting. There is no corresponding provision in favour of a female employee.

${ }^{163}$ Which bans a woman from being employed on night work in a public or any agricultural undertaking except she is a nurse or is employed within the management cadre and not engaged in manual labour.

${ }^{164}$ The section disallows women from engaging in any underground work in any mine.

${ }^{165}$ Cap. L1 Laws of the Federation of Nigeria 2004.
}

166 See for instance, Priye Iyalla Amadi v. The Comptroller General, Nigerian Immigration Services, Suit No. FHC/PH/CS/198/2008, decided on 1 June 2009, per Hon. Justice G. K. Olotu (unreported), where the Federal High Court struck down the requirement by the Nigerian Immigration Services that a married woman who applies for issuance of a new international passport must inter alia attach a document showing the husband's consent. Also in WELA v. Attorney-General of the Federation, Suit No. FHC/IKJ/CS/M128/2010 (unreported), the Federal High Court struck down section 124 of the Police Act which mandates an unmarried woman police to apply for permission from the Commissioner of Police and furnish 30 


\section{Conclusion and Recommendations}

The article investigated the efficacy of some of the legal and policy frameworks made by the government for the protection of women's rights in Nigeria. Unfortunately, some of the laws and policies are fraught with some inherent weaknesses as identified in the article. Other identified external factors or constraints inhibiting the enjoyment of women's rights in the country include the patriarchal nature of the Nigerian society, cultural practices, conservative attitude of our court system and non-domestication and ratification of some relevant human rights instruments on the subject.

In view of the identified challenges and in addition to a number of recommendations earlier made in the article, it is further suggested in relation to the nationality or indigeneity of a married woman that marriage should not automatically render her Stateless or foist upon her the nationality or State of origin of her husband. She should be free to choose which nationality she wishes to retain. This is in line with such international instruments like CEDAW ${ }^{167}$ and the Convention on the Nationality of Married Women. ${ }^{168}$ There is also need to domesticate these instruments in Nigeria to enable them have the force of law. Under international law, it is trite that by signing and ratifying a treaty, State parties have indicated their intent to be bound by and obey the obligations arising from such instrument, although it has not been domesticated at the national level. ${ }^{169}$

As earlier noted in the article, a statute like the VAPP Act prescribes the opening and maintenance of sexual offenders' register where sexual offenders' particulars and pictures could be registered and the list made accessible to members of the public. ${ }^{170}$ While this is commendable, it is submitted that merely opening and maintaining such register would not stop the commission of sexual offences. The government and relevant stakeholders must also create awareness for the eradication of stigmatisation against victims of sexual assaults or violence. This will encourage victims of sexual abuses to speak out failing which the offenders will not be prosecuted and possibly convicted. It is further suggested that a convict's name should not be registered in the sexual offenders register during the pendency of his appeal against his conviction or before the expiration of the statutory period within which he is allowed to appeal. To do otherwise will amount to denying him of his constitutional and statutory right of appeal. ${ }^{171}$ It is common knowledge that some convictions at times may be upturned even at the Supreme Court. The presumption of innocence of a defendant should continue till the final determination of his appeal.

him with certain information regarding her prospective husband before she could be authorised to get married to the intended husband.

${ }^{167}$ See Article 5.

${ }^{168}$ See for example Articles 1, 2 and 3.

${ }^{169}$ G. M. Wachira and A. Ayinla, "Twenty Years of Elusive Enforcement of Recommendations of the African Commission on Human and Peoples' Rights: A Possible Remedy," (2006) 6 African Human Rights Law Journal 465 at 468, 472.

${ }^{170}$ See VAPP Act, section 1 (4). Section 44 thereof goes further to recognise NAPTIP as the regulatory body to administer the VAPP Act

${ }^{171}$ See for instance, the 1999 Constitution sections 233, 240, and 241(1) and NAPTIP Act, section 62. 